\title{
Linking Public Policy SupPort For Ocean SCIENCE TO PRE-COLlege EDUCATION
}

\author{
By Admiral James D. Watkins
}

$\mathrm{Y}$ OU MAY RECALL some of the chilling statements made in the powerful $A$ Nation at Risk report in 1983, a report that triggered recent attempts at educational reform in the United States. In that report, one researcher concluded, after completing a national survey on student achievement within the explosive scientific world we live that, "We are raising a new generation of Americans that is scientifically and technologically illiterate." Similarly, a former Director of the National Science Foundation was quoted as warning of "a growing chasm between a small scientific and technological elite and a citizenry illinformed, indeed uninformed, on issues with a science component." Alas, surveys conducted recently could justify redating this report as being written in 1995 .

My experiences in the military and civilian government as well as at Joint Oceanographic Institutions (JOI) and The Consortium for Oceanographic Research and Education (CORE) confirm the validity of and echo these expressed concerns. For example:

- The Military Services were given the challenge to shift to the All-Volunteer Military in the 1970 s. Since there was no more draft, we no longer could afford to casually reject new volunteer recruits just because they could not meet basic reading, writing, and arithmetic skill requirements, even at the lowest acceptable entrance level. Rather, we had to develop, at great cost, an entirely new in-house capability to re-educate and re-train underpre-

Admiral James D. Watkins is retired from the U.S. Navy where he served as Chief of Naval Operations. Chairman of the Presidential Commission on AIDS and Secretary of Energy. He is currently the President of both the Joint Oceanographic Institutions and The Consortium for Oceanographic Research and Education. pared volunteer/recruits out of high school. This situation was exacerbated by the fact that basic skill requirements had begun to escalate exponentially with rapidly emerging new technologies. It was obvious that our public schools were not even close to meeting minimal educational standards to keep pace. So, the gap only widened further between societal needs and skills available in the newly educated workforce. In fact, we found that 20,000 of the 100,000 high school graduates annually recruited into the Navy at that time could not read and comprehend at the ninth grade reading level (i.e., can you read and understand this sign? "Beware of Jet Blast"). Further, the recruits had little or no computational or writing skills.

- Results of our lengthy nation-wide hearings on the AIDS epidemic revealed almost total ignorance in understanding human biology among the American populace. This situation was recognized to be a direct consequence of an inadequate incorporation of appropriate human biology courses in the $\mathrm{K}-12$ core science curricula.

- At the Department of Energy, I found myself constantly enmeshed in public policy debate in the media on a myriad of technical matters (e.g., nuclear waste disposal, the supercollider, and cold fusion) all of which demanded at least some modest understanding of both some simple scientific principles and a basic middle-school level technical vocabulary with which to exchange simple science concepts. This understanding for the most part was simply not present. The frequent result was unwarranted media-generated apprehension and distrust of science within the large body of our society. This came at a time when so many science- related events were taking place around us-like ozone layer depletion; like achieving clean air or clean water standards; like global climate threats catalyzed by a world population predicted to double in half a century; like accelerated diminution of existing biological diversity; like the seemingly intractable matter of waste disposal, whether toxic, hazardous, or high and low-level radioactive waste; and the list goes on. These are all highly technical issues demanding some conversance with fundamental scientific principles in order to separate scientific fact from fiction.

In all of these cases, the problems i1lustrate the necessity for attempts to remediate the technical illiteracy of adults who may be required to establish or implement science policy. But this is a difficult task since most have never been adequately educated to comprehend the fundamentals of science. Although not a new revelation to many of us, we have only recently begun to accept the research that says all Americans can learn to a higher level, including the fields of mathematics and science. However, this same research admonishes us to recognize that the early years of a child's life are a critical period for sound cognitive development. Alas, most adults today were not beneficiaries of this research, insofar as science and mathematics are concerned.

Scientific illiteracy also manifests itself in other ways. For example, it results too frequently in unnecessarily burdensome, frequently misguided, and excessively costly legislation and regulation based on reelection politics, not science. A politically popular action is often boosted by self-interested activists whose future revenues depend on their effectiveness at taking advantage of public illiteracy and its resultant vulnerability to 
hype. Such activists can often co-opt our lawmakers who can then find it easy and attractive to stay on the side of science fiction at reelection time. A common practice to support a preordained position is to quote only the extreme end of the appropriate uncertainty bar of experimental results. By doing so, politicians feel they have remained within ethical bounds to justify their position. They get away with this warping of scientific uncertainty to fit their own political desires since there is seldom anyone out there listening who is either literate or brave enough to call "foul."

There are some rays of hope. While the national educational picture since the Nation at Risk report has probably deteriorated, or at best remained the same, serious plans for a brighter tomorrow are being implemented (e.g., NSF's systemic reforms) or are on the drawing board. From that report's findings and recommendations one dozen years ago came the seeds for the subsequent historic Conference on Education co-hosted by the President of the United States and all state and territorial governors, held at Charlottesville, Virginia in 1989. From that conference, groundwork for setting national education goals and objectives was laid through a cooperative effort between federal and state governments. This resulted in passage of the Goals 2000: Educate America Act of 1994. Included among the six original goals agreed upon were the setting of: core subjects; standards to be met; methods of assessment; and, important to the ocean science community, the goal "to be number one in math and science by the year 2000 ."

In his February 1995 speech entitled "Vision and Strategy in Science Education Reform," given to the American Association for the Advancement of Science (AAAS), the President of the National Academy of Sciences, Dr. Bruce Alberts, pointed out the importance of science education for all Americans, outlined the skills our children will have to master if they are to be successful competitors in the modern world economy, and then made the case that these skills are "best taught through a system of science education that begins in kindergarten and continues throughout one's lifetime, not science education as science words, but science education as a hands-on, inquirybased experience." He went on, then, to announce that the National Science Education Standards, for which his National
Resource Council has responsibility, will be finalized in the fall of 1995. These, he said, will argue:

- that science should become a core subject starting in kindergarten, like reading, writing, and math;

- that science is not the memorization of words but a process of inquiry, satisfying the need to study a few topics in depth and generating excitement to want to know more . . this is where oceans could fit nicely;

- that all children can learn science and math, that research shows this to be true even though very few Americans believe it.

The ocean science community is uniquely poised to contribute to improving and enhancing science education in this "island nation."

The Consortium for Oceanographic Research and Education (CORE) is dedicated to the advancement of ocean research and education. Composed of 36 U.S. oceanographic institutions, CORE draws upon the substantial scientific expertise of these institutions and the experience of individual scientists in $\mathrm{K}$-graduate education.

As a first step toward carrying out this mission objective, CORE has already completed a successful $\mathrm{K}-12$ math and ocean science initiative with the Smithsonian Institution, and has now been requested by the Smithsonian Institution in partnership with the University of the District of Columbia and the District of Columbia Public School System, to move to the next step towards developing and implementing a dynamic and replicable

Table 1

Tentative traveling schedule for Ocean Planet

\begin{tabular}{|c|c|}
\hline Museum & Booking Period \\
\hline $\begin{array}{l}\text { The Presidio } \\
\text { San Francisco, CA }\end{array}$ & March 30, 1996-June 23, 1996 \\
\hline $\begin{array}{l}\text { Christopher Columbus Center } \\
\text { Baltimore, MD }\end{array}$ & July 27, 1996-October 20, 1996 \\
\hline $\begin{array}{l}\text { Bishop Museum } \\
\text { Honolulu, HI }\end{array}$ & July 12.1997-October 5. 1998 \\
\hline Refurbishment & October 25. 1997-December 28, 1997 \\
\hline $\begin{array}{l}\text { Museum of Science \& Industry } \\
\text { Chicago, IL }\end{array}$ & May 23, 1998-August 15, 1998 \\
\hline $\begin{array}{l}\text { Museum of Science } \\
\text { Boston, MA }\end{array}$ & September 19, 1998-December 13, 1998 \\
\hline
\end{tabular}

educational model to complement the Smithsonian Institution Ocean Planet exhibition. The Ocean Planet exhibition, a project sponsored by the Smithsonian Institution, coupled with the major urban area education component proposed here, represents an ideal opportunity to expose inner-city teachers to the value and excitement in using the oceans as a tool for science education.

A grant from the Carnegie Corporation of New York supported initial planning for this project. Additionally, a grant from the National Science Foundation provided pilot funds to develop and test the feasibility of a teacher training program centered on the exhibition. We have already:

- fully implemented a K-12 math and science teacher training program involving the Ocean Planet exhibition while in Washington, D.C., from April 1995 until March 1996;

- evaluated the success of the program and revised it accordingly; and the next phase will

- plan for exportation of the program as the exhibition travels to six cities across the country through 1999 (see Table 1).

These efforts, centered on ocean sciences, provide a sound model for establishing a strong national program in science education, including directed focus on minority population centers. An educational program carried out by CORE and built around the exhibition provides an excellent learning tool to encourage teachers to incorporate marine studies into science education curricula. This will be accom- 
plished by providing a fundamental understanding of ocean science and issues, classroom lessons and activities, and a high-profile national exhibition to serve as an integrating class experience.

Ocean science education is a simple and economical way to make delivery methods in science education more student-oriented and exciting through an integrated approach. Few disciplines are more suited for teaching the broad spectrum of general science than oceanography, since it is based upon all of the clas- sical scientific fields-physics, chemistry, biology, geology, and mathematics.

By taking advantage of the educational reform movement now underway nationally, by injecting ocean science into the core subject material in $\mathrm{K}-12$, by providing supporting hands-on materials to our under-served science teachers, we may over the long term be able to enhance adult literacy about our earth's most prevalent natural resourceits oceans and the estuaries that feed them. If successful, we can take satisfac- tion in the fact that we in the academic oceanographic community are personally involved in and part of the national effort to reestablish scientific literacy in all Americans. But equally important, our effort is also born out of an urgent need to reaffirm the critical importance to this island nation of the scientific understanding of our oceans as the essential ingredient to national security, quality of life, and economic development. Sure, this will take years, but we're long overdue in starting. 